\title{
Enterotoxigenic Genes in strains of Staphylococcus spp., isolated from cheese made in Pamplona-Colombia
}

\author{
Genes enterotoxigénicos en cepas de Staphylococcus spp., \\ aisladas a partir de queso elaborado en Pamplona-Colombia
}

\author{
Fanny Herrera A, ${ }^{1 *}$ Ph.D, Jesús Santos $B^{2}$ Ph.D.
}

\begin{abstract}
${ }^{1}$ Universidad de Pamplona, Facultad de Ciencias Básicas, Departamento de Microbiología, Grupo de Investigación en Microbiología y Biotecnología (GIMBIO). Ciudad Universitaria, Pamplona, Norte de Santander, Colombia. '2Universidad de León, Facultad de Veterinaria, Departamento de Higiene y Tecnología de los Alimentos. Campus de Vegazana, A.A. Nro. 24071, León, España. *Correspondencia: fannyh@unipamplona.edu.co
\end{abstract}

Received: April 2014; Accepted: November 2014.

\begin{abstract}
Objective. To determine the incidence of coagulase-positive strains of enterotoxigenic Staphylococcus in doble crema (double cream) cheese samples produced in Pamplona. Materials and methods. Bacterial isolation was performed following the routine method for coagulase positive Staphylococcus provided by the Colombian Technical Standard 4779, by using Baird Parker medium with confirmation of typical colonies by performing the coagulase test. Detection of genes for principal enterotoxins was done by PCR. Results. The prevalence of coagulase positive Staphylococcus in cheese samples was $31 \%$, with $27 \%$ of the samples failing to meet the requirements of the NTC 750 . In $24.6 \%$ of the studied isolates, genes for enterotoxin production were detected. The presence, in the isolated strains, of genes for SEB, SEA and SED was $18.5 \%, 4.6 \%$ and $3.0 \%$, respectively. Conclusions. The significant presence of enterotoxigenic genes found in the isolates obtained from samples of double cream cheese made in Pamplona, suggests an important hazard to the health of consumers.
\end{abstract}

Key words: coagulase, cheese, enterotoxins, prevalence, Staphylococcus (Source: MeSH).

\section{RESUMEN}

Objetivo. Determinar la incidencia de cepas de Staphylococcus coagulasa positivas, potencialmente enterotoxigénicas, en muestras de queso doble crema elaborado en Pamplona. Materiales y métodos. Se siguió el método tradicional de aislamiento de Staphylococcus coagulasa positivos estipulado por la Norma Técnica Colombiana 4779, empleando el medio de Baird Parker con confirmación de las colonias típicas mediante la realización de la prueba de la coagulasa. La detección de los genes para las principales enterotoxinas se realizó utilizando la técnica de PCR. Resultados. Se encontró una prevalencia de Staphylococcus coagulasa positivos en el $31 \%$ de las muestras; el $27 \%$ de las muestras incumplieron la NTC 750 . En el $24.6 \%$ de las cepas estudiadas se detectaron genes para producción de enterotoxinas. La presencia, en las cepas aisladas, de genes para ESB, ESA y ESD 
fue de $18.5 \%, 4.6 \%$, y $3.0 \%$, respectivamente. Conclusiones. La significativa presencia de genes enterotoxigénicos encontrada en las cepas obtenidas a partir de las muestras de queso doble crema elaborado en Pamplona, sugiere un importante peligro para la salud de los consumidores.

Palabras clave: Coagulasa, enterotoxinas, prevalencia, queso, Staphylococcus (Fuente: MeSH).

\section{INTRODUCTION}

Foodborne Illnesses (FBI) are a growing problem to public health around the world, resulting in the ingestion of food contaminated with microorganisms, pluricellular organisms (helminthes), chemical and/or toxic substances. The most obvious clinical manifestations of FBIs are gastrointestinal: however, these illnesses can have chronic effects on health, including neurological, gynecological or immunological symptoms, as well as damage multiple organs, and cause cancer or death (1).

One of the most important etiologic agents of FBIs in the world is Staphylococcus aureus. The term "staphylococci" defines a group of Gram positive coco bacteria that divide on more than one plane to form three-dimensional cell bunches. Staphylococcus belongs to order I Bacillales of the Staphylococcaceae family (2); 18 species of Staphylococcus that affect food have been described, and coagulase positive ones such as $S$. aureus is the one that is most transmitted by food (3).

Staphylococci are normal inhabitants of the body surface of the majority of warm blooded animals, present in mucous and skin, and for this reason the most important source of these bacteria in food are nasal passages and food handlers that have wounds and/or boils on hands and arms; additionally, domestic animals such as cows can be bearers of this bacteria, since $S$. aureus is an important mastitis producer in milk-producing females, which contaminates cheese made from it (3).

Staphylococcus aureus produces a wide range of substances associated with virulence, among them enzymes, cytotoxins, exotoxins, exfoliative toxins and enterotoxins (4).

The main factor for virulence of Staphylococcus involved in staphylococcal food poisoning (SFP) is the production of enterotoxins (SE). S. aureus produces five typical toxins: SEA, SEB, SEC, SED and SEE, which produce emesis in primates. The enterotoxins that are best characterized are ESA and ESB; the most frequent outbreaks of ETAs are ESA and ESP (4). S. aureus enterotoxins are thermostable, and thus resist thermal treatments to which food is subjected (3).

\section{INTRODUCCIÓN}

Las Enfermedades de Origen Alimentario (ETAs) son un problema creciente de salud pública en todo el mundo, resultando de la ingestión de alimentos contaminados con microorganismos, organismos pluricelulares (helmintos), sustancias químicas y/o toxinas. Las manifestaciones clínicas más evidentes de las ETAs son de tipo gastrointestinal: sin embargo, estas enfermedades pueden tener efectos crónicos sobre la salud, incluyendo síntomas neurológicos, ginecológicos o inmunológicos, como también daño a múltiples órganos, cáncer y la muerte (1).

Dentro de los agentes etiológicos más importantes de ETAs en el mundo se encuentra Staphylococcus aureus. El término "estafilococos" define un grupo de bacterias en forma de cocos Gram-positivos que se dividen en más de un plano para formar racimos tridimensionales de células. El género Staphylococcus, pertenece al orden I Bacillales, familia Staphylococcaceae (2); se han descrito 18 especies de Staphylococcus de importancia en alimentos, siendo, las especies coagulasa-positivas como $S$. aureus las que más se transmiten por alimentos (3).

Los estafilococos son habitantes normales de las superficies corporales de la mayoría de los animales de sangre caliente, encontrándose en las mucosas y en la piel, por esta razón la fuente más importante de estas bacterias en los alimentos son los portadores nasales y las personas con heridas y/o forúnculos en manos y brazos que manipulan los alimentos; adicionalmente, animales domésticos como vacas pueden ser portadores de esta bacteria ya que S. aureus es importante productor de mastitis en hembras lecheras contaminando el queso elaborado con la misma (3).

Staphylococcus aureus produce una gama amplia de sustancias asociadas con la virulencia, entre ellas enzimas, citotoxinas, exotoxinas, toxinas exfoliativas y enterotoxinas (4).

El principal factor de virulencia de Staphylococcus involucrado en la intoxicación alimentaria estafilocócica (IAE) es la producción de enterotoxinas (SE). S. aureus produce cinco toxinas típicas: SEA, SEB, SEC SED y SEE las cuales producen emesis en primates. Las enterotoxinas mejor caracterizadas son la ESA y ESB; las más frecuentes en brotes de ETAs son la ESA y la ESB (4). Las enterotoxinas de $S$. aureus 
FBI is acquired when consuming food where the microorganism has preformed one or several of its enterotoxins. Symptoms generally develop 6 hours after ingesting contaminated food, characterized by vomiting, nausea, abdominal spasms and diarrhea. It can cause death in persons whose autoimmune system is compromised. FBI is self-limiting and is not a notifiable illness, which means that many outbreaks and cases are not reported. In the United States of America (USA) it has been calculated that only from 1 to $5 \%$ of all food poisoning cases are reported; however, it is estimated that it causes $14 \%$ of the FBIs in the country (5). S. aureus is considered one of the principal agents causing FBIs in the world, and the pathogen is more frequently associated with cheese made with raw milk (6).

In the United States, it is calculated that more than 241,000 domestic cases of staphylococcal food poisoning (SFP) occur annually; keeping in mind that the hospitalization rate is $6.4 \%$ for confirmed laboratory cases, an average of 1,064 of these cases were hospitalized, resulting in 6 deaths (7). In France in 2008, S. aureus was confirmed as the second causative agent of FBIs after Salmonella and is the first suspected agent in $42.5 \%$ of $\mathrm{FBI}$ outbreaks.

In Latin America many types of fresh artisan cheese exist; within FBIs are SFPs. In provinces of countries in the region, such as Cuba and Argentina, $S$. aureus has been one of the principal bacteria implicated in FBI outbreaks in periods from 2004-2008 and 1993-2001, respectively, with artisan cheese being an important food involved in those outbreaks $(8,9)$.

In Colombia, $S$. aureus is found among the principal microorganisms that are on the FBI surveillance network (10). Among published outbreaks is one that happened in the Atlantic Department in a school cafeteria from the Santo Tomás municipality and one that happened in the Honda municipality (Tolima), which affected people who participated in a community event; the causative agent in these outbreaks was $S$. aureus $(11,12)$.

The objectives of this study were to detect the prevalence of positive Staphylococcus coagulasa in doble crema (double cream) cheese made in the city of Pamplona, establishing if the analyzed cheese samples did or did not comply with the allowable limits for this bacteria as established by the Colombian Technical Standard (NTC) 750, and also to determine the presence of genes that codify ESA, ESB, ESC, ESD and ESE enterotoxins in positive Staphylococcus coagulasa strains by means of the Polymerase Chain Reaction (PCR). son termoestables, de tal manera que resisten los tratamientos térmicos a los cuales se someten los alimentos (3).

La IAE, se adquiere al consumir un alimento en el cual el microorganismo ha preformado una o varias de sus enterotoxinas. Los síntomas se desarrollan, generalmente, 6 horas después de la ingestión del alimento contaminado, caracterizándose por vómitos, náuseas, espasmos abdominales y diarrea. En personas inmunocomprometidas puede ocasionar la muerte. La IAE es autolimitante y no es una enfermedad de declaración obligatoria, aspectos que hacen que muchos brotes y casos no se informen. En los Estados Unidos de Norteamérica (USA) se ha calculado que sólo son declarados entre el 1 y el $5 \%$ de todos los casos por esta intoxicación, a pesar de esto, se estima que es la causante del $14 \%$ de ETAs en ese país (5). Se considera que $S$. aureus es uno de los principales agentes causales de ETAs en el mundo, y es el patógeno más frecuentemente asociado a quesos elaborados con leche cruda (6).

En USA, se calcula que ocurren más de 241,000 casos domésticos de IAE anualmente; teniendo en cuenta una tasa aproximada de hospitalización del $6.4 \%$, para los casos confirmados en el laboratorio, en promedio 1,064 de estos casos fueron hospitalizados resultando en 6 muertes (7). En Francia, en el 2008, fue confirmado $S$. aureus como el segundo agente causal de ETAs después de Salmonella y se le considera el primer agente sospechoso del $42.5 \%$ de los brotes de ETAs (6).

En Latinoamérica existen muchos tipos de quesos frescos artesanales; dentro de las ETAs se destaca la IAE. En provincias de países de la región como Cuba y Argentina, $S$. aureus ha sido de las principales bacterias implicadas en brotes de ETAs en los períodos 2004-2008 y 1993-2001, respectivamente, resultando el queso artesanal un importante alimento involucrado en los mismos $(8,9)$.

En Colombia, S. aureus se encuentra entre los principales microorganismos que se declaran en la red de vigilancia de ETAs (10). Dentro de los brotes publicados se destacan el sucedido en el departamento del Atlántico en el comedor de un colegio del municipio de Santo Tomás y el ocurrido en el municipio de Honda (Tolima) el cual afectó a personas que participaban de un evento comunitario; en estos brotes se implicó como agente causal principal a S. aureus $(11,12)$.

Los objetivos del presente trabajo fueron detectar la prevalencia de Staphylococcus coagulasa positivos en muestras de queso doble crema artesanal elaborado en la ciudad de Pamplona, estableciendo si las muestras de queso analizadas cumplían o no con los límites permisibles para esta bacteria establecidos por la Norma Técnica Colombiana (NTC) 750 y también 


\section{MATERIALS AND METHODS}

Sampling. Over the course of a year, 100 samples of $200 \mathrm{~g}$ of doble crema (double cream) cheese made in Pamplona and sold in formally established places were collected. The samples were refrigerated and transported in the same conditions for immediate microbiological analysis.

Isolation of Staphylococcus. The NTC 4779 recommendation (13) was followed: $10 \mathrm{~g}$ of the sample was taken and homogenized in $90 \mathrm{~mL}$ of $0.1 \%$ peptonized water (Oxoid, Basingstoke, United Kingdom), making decimal dilutions up to $10^{-3}$; later $0.1 \mathrm{~mL}$ of dilutions $10^{-3}$ y $10^{-2}$ were piped (depending on the sample, at times $10^{-1}$ and $10^{-2}$ o $10^{-3}$ and $10^{-4}$ dilutions were inoculated) on the previously prepared surface of the Baird Parker medium (Oxoid); the inoculated dilution was spread with the help of a Drigalsky loop until the surface was very dry, incubating at $35 \pm 2^{\circ} \mathrm{C}$ for 48 hours. After the incubation time, plates that contained from 20-200 black, shiny colonies were selected having white shrunken borders and surrounded by clear areas that contrasted with the opaque medium, areas with precipitated calcium and magnesium salts, which were then counted; a minimum of three colonies were used for the coagulase test.

Testing the coagulase. The number of colonies to be confirmed were transferred in the same number of tubes that contained $5 \mathrm{~mL}$ of Brain Heart Infusion broth (BHI, Oxoid), concluding a positive control, incubating at $35 \pm 2{ }^{\circ} \mathrm{C}$ for $18-24$ hours. After this time, $0.3 \mathrm{~mL}$ of each $\mathrm{BHI}$ broth was put into tubes that contained $0.3 \mathrm{~mL}$ of dehydrated plasma of rabbit-EDTA (bioMerieux SA, Marcy l'Etoile, France), and a tube of $0.3 \mathrm{~mL}$ of plasma as a negative control was also transferred, incubating at $35 \pm 2{ }^{\circ} \mathrm{C}$. For the first six hours they were observed hourly, in negative cases the reading was extended to 24 hours. Once finalized the incubation time, the results were interpreted, based on tubes that presented plasma coagulation, comparing them with positive and negative controls. The calculation of positive Staphylococcus coagulasa was done keeping in mind the total number of colonies after 48 hours of incubation and the proportion of colonies confirmed for the coagulase test, using as a correction factor the relation: positive colonies/ examined colonies, reporting Colony Forming Units $(\mathrm{CFU}) / \mathrm{g}$.

Detecting enterotoxigenic genes. From the positive coagulase strains cultivated in Soy Tripticase broth (Oxoid) and incubated at $37^{\circ} \mathrm{C}$ for 24 hours, $1 \mathrm{~mL}$ was transferred, centrifuged in a Eppendorf 5415D micro centrifuge at 12,000 $\mathrm{rpm} / 3 \mathrm{~min}$. Later $200 \mu \mathrm{L}$ of Chelex (Bio-Rad, determinar la presencia de genes que codifican las enterotoxinas ESA, ESB, ESC, ESD y ESE, en las cepas de Staphylococcus coagulasa positivas, mediante la realización de la Reacción en Cadena de la Polimerasa (PCR).

\section{MATERIALES Y METODOS}

Muestreo. Durante el lapso de un año, se recolectaron 100 muestras de $200 \mathrm{~g}$ de queso doble crema elaborado en Pamplona, expendido en lugares formalmente establecidos. Las muestras fueron refrigeradas y transportadas en las mismas condiciones y realizando los análisis microbiológicos inmediatamente.

Aislamiento de Staphylococcus. Se siguió el protocolo recomendado por la NTC 4779 (13), así: se tomaron $10 \mathrm{~g}$ de la muestra y se homogeneizaron en $90 \mathrm{~mL}$ de agua peptonada $0.1 \%$ (Oxoid, Basingstoke, United Kingdom), realizando diluciones decimales hasta 10 $10^{-3}$; posteriormente se pipeteó $0.1 \mathrm{~mL}$ de las diluciones $10^{-3}$ y $10^{-2}$ (dependiendo de la muestra en algunos casos se inocularon las diluciones $10^{-1} \mathrm{y}$ $10^{-2}$ ó $10^{-3}$ y $10^{-4}$ ) sobre la superficie del medio Baird Parker (Oxoid), previamente preparado; se extendió el inóculo con ayuda de un asa de Drigalsky hasta que la superficie quedó bien seca, incubando a $35 \pm 2^{\circ} \mathrm{C}$ durante 48 horas. Transcurrido el período de incubación se seleccionaron las placas que contenían entre 20-200 colonias negras y brillantes con bordes reducidos blancos, rodeadas de zonas claras que contrastan con el medio opaco, zona de precipitado de sales de calcio y magnesio, las cuáles fueron contadas; se tomó un mínimo de tres colonias para realizar la prueba de la coagulasa.

Prueba de la coagulasa. Se transfirió el número de colonias a confirmar en un mismo número de tubos que contenían $5 \mathrm{~mL}$ de caldo Infusión Cerebro Corazón (BHI, Oxoid), incluyendo un control positivo, incubando a $35 \pm 2{ }^{\circ} \mathrm{C}$ durante $18-24$ horas. Pasado este tiempo, se pasaron $0.3 \mathrm{~mL}$ de cada caldo $\mathrm{BHI}$ a tubos que contenían $0.3 \mathrm{~mL}$ de plasma deshidratado de conejo-EDTA (bioMerieux SA, Marcy I'Etoile, France), igualmente se transfirió a un tubo $0.3 \mathrm{~mL}$ del plasma como control negativo, incubando a $35 \pm 2^{\circ} \mathrm{C}$. Se observó cada hora durante las primeras seis horas, en caso negativo se realizó la lectura hasta las 24 horas. Una vez finalizado el tiempo de incubación, se interpretaron los resultados, con base en los tubos que presentaron coagulación del plasma, comparándolos con los controles positivos y negativos. Se realizó el cálculo de Staphylococcus coagulasa positivo teniendo en cuenta el número total de colonias después de las 48 horas de incubación y la proporción de colonias confirmadas por la prueba de la coagulasa, utilizando como factor de corrección la relación: colonias positivas/colonias examinadas, informando Unidades Formadoras de Colonia (UFC)/g. 
Hércules, California, USA) was added, the pellet was completely re-suspended and incubated at $56^{\circ} \mathrm{C}$ for $30 \mathrm{~min}$. Each tube was agitated in a vortex for 10 seconds; later each tube was placed on a heating block (JP Selecta S.A, Barcelona) at $100^{\circ} \mathrm{C}$ for 8 minutes. Then each tube was again agitated and finally centrifuged at 12,000 $\mathrm{rpm} / 3 \mathrm{~min}$. The concentration of DNA used was quantified using a Spectrophotometer-UV Q3000 (Quawell, Beijing, China). Using $3 \mu \mathrm{L}$ of the DNA (50 $\mathrm{ng} / \mu \mathrm{L}$ approximately) the PCR was done, and for this, corresponding pairs of primers for each enterotoxin were used at a concentration of $25 \mathrm{mM}$ and a commercial cocktail, 5 PRIME MasterMix (Taq polimerase, buffer, dNTPs y $\mathrm{Mg}^{+2}$ ) (5 PRIME Hamburg, Germany). Different genes were amplified in a Mastercycler Personal (Eppendorf, Hamburg, Germany); the sequence of the primers used and the length of the amplified ones are shown in table 1 (14).

Table 1. Genes, primers, hybridization temperatures, and sizes expected in amplicons used to determine the presence of enterotoxin genes in positive S.aureus coagulase strains.

\begin{tabular}{|c|c|c|c|}
\hline Gen & $\begin{array}{l}\text { Primer Sequence } \\
\left(5^{\prime} \text { a } 3^{\prime}\right)\end{array}$ & $\mathrm{TH}\left({ }^{\circ} \mathrm{C}\right)$ & $\operatorname{LEA}(p b)$ \\
\hline sea & $\begin{array}{l}\text { ACGATCAATTTTACAGC } \\
\text { TGCATGTIITCAGAGTAATC }\end{array}$ & 56 & 544 \\
\hline seb & $\begin{array}{l}\text { GAATGATATTAATTCGCATC } \\
\text { TCTTTGTCGTAAGATAAACTTC }\end{array}$ & 55 & 416 \\
\hline $\mathrm{sec}$ & $\begin{array}{l}\text { GACATAAAAGCTAGGAATTT } \\
\text { AAATCGGATTAACATTATCCA }\end{array}$ & 56 & 257 \\
\hline sed & $\begin{array}{l}\text { TTACTAGTTTGGTAATATCTCCTT } \\
\text { CCACCATAACAATTAATGC }\end{array}$ & 58 & 334 \\
\hline see & $\begin{array}{l}\text { ATAGATAAAGTTAAAACAAGCAA } \\
\text { TAACTTACCGTGGACCC }\end{array}$ & 52 & 170 \\
\hline
\end{tabular}

TH: Temperature of hybridization; LEA: Expected amplicon length

The amplification products $(5 \mu \mathrm{l})$ were subjected to electrophoresis in agarose gel (Bio-Rad) at $1 \% \mathrm{p} / \mathrm{v}$ at $100 \mathrm{~V}$ for $1 \mathrm{~h}$. Visualization was done by means of staining with RedSafeTM (iNtRon Biotechnology, INC., Sungnam, Kyungki-Do, Korea), using a transiluminator ultraviolet light, Mini-Transiluminator (Bio-Rad) and documented with the Digimage System application connected to a Canon Power Shot G11 digital camera (Major Science, Taipei, Taiwan).

\section{RESULTS}

The prevalence of positive Staphylocuccus coagulase (SCP) in the analyzed samples was $31 \%$. Additionally, $27 \%$ of the samples did not comply with NTC 750 (15), which establishes the microbiological requirements (among them positive Staphylococcus coagulase), for fresh cheese (Table 2). In $23 \%$ of the samples a
Detección de genes enterotoxigénicos. A partir de las cepas coagulasa positivas crecidas en caldo Tripticasa de Soja (Oxoid), e incubadas a $37^{\circ} \mathrm{C}$ durante 24 horas, se transfirió $1 \mathrm{~mL}$, centrifugando en una microcentrífuga Eppendorf 5415D a 12,000 rpm/3 min. Posteriormente se adicionaron $200 \mu \mathrm{L}$ de Chelex (Bio-Rad, Hércules, California, EEUU), resuspendiendo el "pellet" completamente e incubando a $56^{\circ} \mathrm{C}$ por 30 min. Se agitó cada tubo empleando un vortex durante 10 segundos; luego se transfirió cada tubo a un bloque de calentamiento (JP Selecta S.A, Barcelona) a $100^{\circ} \mathrm{C}$ durante 8 minutos. Nuevamente se agitó cada tubo y finalmente se centrifugó a 12,000 rpm /3 min. Se cuantificó la concentración de ADN empleando un Espectrofotómetro-UV Q3000 (Quawell, Beijing, China). Partiendo de $3 \mu \mathrm{L}$ del ADN ( $50 \mathrm{ng} / \mu \mathrm{L}$ aproximadamente) se llevó a cabo la PCR, para esto, se emplearon los pares de cebadores correspondientes para cada enterotoxina a una concentración de $25 \mathrm{mM}$ y un cóctel comercial 5 PRIME MasterMix (Taq polimerasa, buffer, dNTPs y $\mathrm{Mg}^{+2}$ ) (5 PRIME Hamburgo, Alemania). Fueron amplificados los diferentes genes en un equipo Mastercycler Personal (Eppendorf, Hamburgo, Alemania); la secuencia de los cebadores empleados y la longitud de los amplificados se muestran en la tabla 1 (14).

Se sometieron los productos de la amplificación $(5 \mu \mathrm{l})$ a electroforesis en gel de agarosa (BioRad) al $1 \% \mathrm{p} / \mathrm{v}$ a $100 \mathrm{~V}$ durante $1 \mathrm{~h}$. Se realizó la visualización mediante tinción con RedSafeTM (iNtRon Biotechnology, INC., Sungnam, Kyungki-Do, Korea), empleando un transiluminador de luz ultravioleta, Mini-Transiluminador (Bio-Rad) y documentando con la aplicación del Digimage System acoplado a una cámara digital Canon Power Shot G11 (Major Science, Taipei, Taiwan).

\section{RESULTADOS}

La prevalencia de Staphylocuccus coagulasa positivos (SCP) en las muestras analizadas fue del $31 \%$. Adicionalmente, el $27 \%$ de las muestras incumplieron la NTC 750 (15), que establece los requisitos microbiológicos (entre ellos Staphylococcus coagulasa positivos), para queso fresco (Tabla 2). En el $23 \%$ de las muestras, se encontró una concentración de SCP mayor o igual a $10^{4} \mathrm{UFC} / \mathrm{g}$.

De 65 cepas estudiadas se detectaron genes que codificaron para la producción de las enterotoxinas investigadas en el $24.6 \%$ de las cepas, las cuáles fueron aisladas a partir de 12 muestras. La prevalencia de genes para ESB, ESA y ESD en estas cepas fue de $18.5 \%, 4.6 \%$, y $3.0 \%$, respectivamente (Tabla 3, Figura 1). En una de las cepas estudiadas se detectaron los genes para las ESA y ESB simultáneamente. No se detectó la presencia de genes para producción de ESC ni ESE. 
concentration of SCP greater or equal to $10^{4}$ UFC/g was found.

Of the 65 strains studied, genes that codified for the production of enterotoxins were found in $24.6 \%$ of the strains, which were isolated from 12 samples. The prevalence of genes for ESB, ESA and ESD in these strains was $18.5 \%, 4.6 \%$, and $3.0 \%$, respectively (Table 3 , Figure 1 ). In one of the strains studied genes detected for ESA and ESB simultaneously. The presence of genes to produce ESC or ESE was not detected.



Figure 1: Example obtained for each one of the detected enterotoxins: $M$ : pattern of molecular size $100 \mathrm{pb} ; 1$ : Strain ESA (+) ATCC (American Type Culture Collection) 13565; 2: Isolated cheese strain; 3: Strain ESB (+) CECT (Colección Española de Cultivos Tipo) 4459; 4-5: Isolated cheese strains; 6: Strain ESD (+) ATCC 23235; 7: Isolated cheese strain.

\section{DISCUSSION}

A high prevalence of SCP was found in the samples. These results concur with those found by Mendonça et al (16), who analyzed samples of fresh cheese sold in Brazil, determining a prevalence of $30.9 \%$; similarly, data found by Maldonado and Llanca (17) in samples of cheese sold in Girardot, Aragua State, Venezuela, found SCP in $25 \%$ of the analyzed samples. However, these results are different from those found by other authors such as Rodríguez et al (18), who were not able to isolate SCP in samples of artisan cheese sold in Upata, Bolivar, Venezuela. Can and Celik (19) analyzed samples of cheese from Turkey, detecting SPC in $9.5 \%$ of the cheese samples. Jakobsen et al (20) detected SCP in $47.3 \%$ of samples of fresh artisan cheese made in Norway. In Colombia, Vanegas et al (10) isolated SCP in $100 \%$ of the samples sold in stores, on the street and in markets in Bogota.
Table 2. Quality of double cream samples studied according to the positive Staphylococcus coagulase count.

\begin{tabular}{ccc}
\hline UFC/g & $\begin{array}{c}\text { \% SAMPLES } \\
(\mathbf{N = 1 0 0})\end{array}$ & QUALITY CRITERIA \\
\hline$\leq 100$ & 72 & Good \\
$>100-1000$ & 1 & Marginally acceptable \\
$>1000$ & 27 & Inacceptable \\
\hline
\end{tabular}

1: according to NTC 750

Table 3. Relationship of samples and strains in which the studied enterotoxinogenic genes were detected.

\begin{tabular}{ccc}
\hline SAMPLE & STRAIN & DETECTED ENTEROTOXENIC GEN \\
\hline 9 & 8 & ESD \\
12 & 9 & ESD \\
29 & 15 & ESB \\
29 & 16 & ESB \\
50 & 45 & ESB \\
54 & 54 & ESA \\
67 & 57 & ESA \\
70 & 59 & ESA/ESB \\
70 & 60 & ESB \\
78 & 61 & ESB \\
78 & 62 & ESB \\
78 & 63 & ESB \\
80 & 64 & ESB \\
82 & 65 & ESB \\
83 & 66 & ESB \\
84 & 67 & ESB \\
\hline
\end{tabular}

\section{DISCUSIÓN}

Se encontró una alta prevalencia de SCP en las muestras. Estos resultados concuerdan con los hallados por Mendonça et al (16) quienes analizaron muestras de queso fresco expendido en Brasil, determinando una prevalencia del 30.9\%; de igual forma se relaciona con los datos hallados por Maldonado y Llanca (17), en muestras de queso comercializado en Girardot estado Aragua, Venezuela quienes encontraron SCP en el $25 \%$ de las muestras analizadas. Sin embargo, estos resultados distan de los hallados por otros autores como Rodríguez et al (18) quienes no lograron aislar SCP en muestras de queso artesanal comercializado en Upata, Bolivar, Venezuela. Can y Celik (19) analizaron muestras de queso de origen turco, detectando SCP en el $9.5 \%$ de las muestras de queso. Jakobsen et al (20), detectaron SCP en el $47.3 \%$ de muestras de queso fresco elaborado artesanalmente en Noruega. En Colombia, Vanegas et al (10) aislaron SCP en el 100\% de muestras de queso expendido en tiendas, ventas callejeras y mercados de la ciudad de Bogotá. 
On the other hand, an important percentage of samples did not comply with Colombian legislation that regulates these products (15). Different results were found by Giammanco et al, who determined that only $4 \%$ of the samples of traditional, fresh Sicilian cheese did not comply with European legislation ( $>10^{3} \mathrm{CFU} / \mathrm{g}$ ) (17). However, authors such as Maldonado and Llanca determined that $100 \%$ of samples of fresh cheese in the form of cakes sold in Girardot, Aragua State, Venezuela, did not comply with Covenin, the Venezuelan Commission of Industrial Regulations ( $>10^{4} \mathrm{CFU} / \mathrm{g}$ ). Luján et al (22) determined that $80 \%$ of the samples of fresh artisan cheese sold in three districts of Lima, Peru, did not comply with the Peruvian Technical Standards ( $>10^{2} \mathrm{CFU} / \mathrm{g}$ ). Komatsu et al (23) detected that $88 \%$ of the samples of cheese made in the city of Uberlândia, Brazil, did not comply with the standards established by the Ministry of Health for $S$. aureus $\left(5.0 \times 10^{2} \mathrm{CFU} / \mathrm{g}\right)$.

The gene that codifies ESB was the main enterotoxic gene detected in this study, followed by ESA; results concur with the findings of Gücükoğlu et al (24), who analyzed samples of ice cream and found that the main enterotoxin produced was ESB. Valero-Leal (25) also found that ESB was the main enterotoxin detected in samples of milk and fresh cow cheese from Zulia State (Venezuela). On the other hand, Vanegas et al (10) detected ESA in $100 \%$ of the SCP strains isolated from artisan cheese from Bogota.

It has been determined that ESB is responsible for close to $10 \%$ of FBIs in the USA (4). Its lethal dose 50 (LD50) is $0.02 \mathrm{mcg} / \mathrm{kg}(26)$, and concentrations of this toxin of just $0.4 \mu \mathrm{g} / \mathrm{kg}$ can induce symptoms in humans; additionally, it has been observed that individuals exposed to ESB manifest more severe symptoms than those exposed to ESA (5). On the other hand, it has been demonstrated that this enterotoxin maintains biological activity after heating to 60 ${ }^{\circ} \mathrm{C}$ for 16 hours, and the optimum temperature for producing it in cultures is $39.4^{\circ} \mathrm{C}$ (3), conditions that favor its presence in fresh cheese.

An important percentage of samples analyzed found a concentration of SCP greater or equal to $10^{4} \mathrm{CFU} / \mathrm{g}$; the lowest number of $S$. aureus cells required to produce the minimum level of enterotoxins considered necessary to provoke illness depends on the type of enterotoxin. For example, ESA has been detected in concentrations of $10^{4} \mathrm{CFU} / \mathrm{g}$ (3); it is recognized, in general, that this value is found between $10^{5}-10^{8} \mathrm{CFU} / \mathrm{g}$ (5). However, there is data from reported SFP outbreaks in which SCP counts are from $7.6 \mathrm{x}$ $10^{2}(27)$, a concentration found in $33 \%$ of the samples analyzed in this study.
Por otro lado, un importante porcentaje de muestras incumplieron la legislación colombiana que reglamenta estos alimentos (15). Resultados diferentes hallaron Giammanco et al, quienes determinaron que sólo el $4 \%$ de las muestras de queso fresco tradicional siciliano incumplían la legislación europea $\left(>10^{3}\right.$ UFC/g) (17). Sin embargo, otros autores como Maldonado y Llanca determinaron que el $100 \%$ de las muestras de queso fresco en forma de torta expendido en Girardot, estado Aragua, Venezuela incumplían la norma de la Comisión Venezolana de Normas Industriales Covenin ( $>10^{4} \mathrm{UFC} / \mathrm{g}$ ). Luján et al (22) determinaron que el $80 \%$ de muestras de queso fresco artesanal comercializado en tres distritos de Lima, Perú, incumplían la Norma Técnica Peruana ( $>10^{2}$ UFC/g). Komatsu et al (23) detectaron que el $88 \%$ de las muestras de queso elaborados en la ciudad de Uberlândia, Brasil, incumplían la norma establecida por el Ministerio de Salud para S. aureus $\left(5.0 \times 10^{2} \mathrm{UFC} / \mathrm{g}\right)$.

El gen que codifica la ESB fue el principal gen enterotóxico detectado en este estudio, seguido de la ESA; resultado que concuerda con los hallados por Gücükoğlu et al (24) quienes analizando muestras de helado de crema, y encontraron que la principal enterotoxina producida fue la ESB. Valero-Leal (25), también hallaron que la ESB fue la principal enterotoxina detectada en muestras de leche y queso freso de vaca originarios del estado Zulia (Venezuela). Por otro lado Vanegas et al (10), detectaron la ESA en el $100 \%$ de las cepas SCP aisladas a partir de queso artesanal procedente de Bogotá.

Se ha determinado que la ESB es responsable de cerca del $10 \%$ de los brotes de ETAs en USA (4). Su dosis letal 50 (LD50) es $0.02 \mathrm{mcg} / \mathrm{kg}$ (26), concentraciones de esta toxina de tan solo $0.4 \mu \mathrm{g} / \mathrm{kg}$ pueden inducir los síntomas en humanos; adicionalmente, se ha observado, que individuos expuestos a la ESB manifiestan síntomas más severos que los expuestos a la ESA (5). De otra parte, se ha demostrado que esta enterotoxina retiene su actividad biológica luego del calentamiento a $60^{\circ} \mathrm{C}$ durante 16 horas, y la temperatura óptima para su producción en medio de cultivo es de $39.4^{\circ} \mathrm{C}$ (3), condiciones que favorecen su presencia en queso fresco.

En un porcentaje importante de las muestras analizadas, se encontró una concentración de SCP mayor o igual a $10^{4} \mathrm{UFC} / \mathrm{g}$; el menor número de células de $S$. aureus requeridos para la producción del nivel mínimo de enterotoxinas considerado necesario para provocar enfermedad depende del tipo de enterotoxina, por ejemplo la ESA se ha detectado en concentraciones de $10^{4} \mathrm{UFC} / \mathrm{g}$ (3); se reconoce, en general, que este valor se encuentra entre $10^{5}-10^{8}$ UFC/g (5). Sin embargo, existen datos de brotes de IAE en los cuales se reportaron recuentos de SCP desde $7.6 \times 10^{2}(27)$, concentración encontrada en el $33 \%$ de las muestras analizadas en este trabajo. 
Double cream cheese in Pamplona is made using raw milk and applying artisan processes where intrinsic and/or extrinsic factors do not exist that limit or control the presence of Staphylococcus aureus. Stretching, which is done between $40^{\circ} \mathrm{C}$ and $42^{\circ} \mathrm{C}$, allows growth, since it can grow up to $47.8^{\circ} \mathrm{C}$; the $\mathrm{pH}$ of the finished product $(5.3-$ 5.6) does not control growth or the spread of this bacteria, since it can grow in $\mathrm{pH}$ of up to 4.0 ; the percentage of salt in the cheese $(3.47 \%$ $\mathrm{NaCl}$ ), is not considered a limitation for this bacteria, since it is halotolerant and can survive in salt concentrations of up to $20 \% \mathrm{p} / \mathrm{p}$ (5). Additionally, contamination can occur in any stage of production, since making the product implies intense contact with handlers, utensils, environments, among others. These stages are done at temperatures above $25^{\circ} \mathrm{C}$ that favor the spread of the bacteria, since $S$. aureus has a generation time of $0.8 \mathrm{~h}$ at this temperature (28) and therefore produces enterotoxins.

On the other hand, the presence of this bacteria in this type of cheese could indicate contamination on the skin, mouth or nasal passages of handlers that came into direct contact with the food and did not follow minimal hygiene standards, such as the use of gloves, mouth coverings, caps or protective clothing, as well as poor cleaning of surfaces, equipment and utensils, which could be seen in some dairy microbusinesses in the province of Pamplona (29). Other sources of contamination could be milk with mastitis, work equipment and tools, air, dust and water. It is evident that inadequate cleaning and disinfecting practices increase the persistence of the bacteria in cheese processing equipment and environments, and the demonstrated resistance of S.aureus to disinfectants when a biofilm is formed is added to this (30).

In conclusion, a high prevalence of Staphylococcus was found in samples of double cream cheese made in Pamplona, reflecting inadequate hygiene practices and disinfection used all along the processing chain, so that it is necessary to train food handlers in Good Manufacturing Practices. Additionally, the storage temperature of milk and the finished product should be controlled so as to minimize the spread of the bacteria.

Finding enterotoxigenic genes in $24.6 \%$ of the analyzed strains that correspond to the toxins that are most frequently found in FBI outbreaks indicates that double cream cheese made in Pamplona can be a public health risk.
La elaboración del queso doble crema, en Pamplona, se realiza empleando leche cruda como materia prima, aplicando procesos artesanales en los que no existen factores intrínsecos y/o extrínsecos, que limiten o controlen la presencia de Staphylococcus aureus: en primer lugar la etapa de hilado, que se realiza entre $40^{\circ} \mathrm{C}$ y $42^{\circ} \mathrm{C}$, permite su crecimiento ya que puede crecer hasta los $47.8^{\circ} \mathrm{C}$; el pH del producto terminado (5.3-5.6) no controla el crecimiento ni la multiplicación de esta bacteria porque puede crecer a $\mathrm{pH}$ incluso de 4.0 ; el porcentaje de sal del queso $(3.47 \%$ $\mathrm{NaCl}$, no se considera limitante para esta bacteria ya que es halotolerante soportando concentraciones de sal hasta del $20 \% \mathrm{p} / \mathrm{p}$ (5). Adicionalmente, se puede presentar contaminación en cualquier etapa del proceso de elaboración ya que la obtención del producto implica etapas con elevado contacto con manipuladores, utensilios, ambientes, entre otros, etapas que se realizan a temperaturas superiores a $25^{\circ} \mathrm{C}$ que favorecen la multiplicación de la bacteria, ya que $S$. aureus presenta un tiempo de generación en la leche de $0.8 \mathrm{~h}$ a esta temperatura (28), y por ende la producción de enterotoxinas.

Por otra parte, la presencia de esta bacteria en este tipo de queso podría indicar contaminación a partir de la piel, boca o fosas nasales de los manipuladores que entraron en contacto directo con el alimento y no contaban con las mínimas normas de higiene, como el uso de guantes, tapa bocas, gorros y batas, además de la deficiente higiene de superficies, equipos y utensilios, lo cual pudo comprobarse en algunas microempresas lácteas de la provincia de Pamplona (29). Otras fuentes de contaminación pueden ser, leche con mastitis, equipos y utensilios de trabajo, aire, polvo y agua. Es evidente que inadecuadas prácticas de limpieza y desinfección aumentan la persistencia de la bacteria en los equipos y ambientes de procesamiento del queso; a esto hay que sumar la demostrada resistencia de S.aureus a desinfectantes cuando forma biopelículas (30).

En conclusión, se encontró una alta prevalencia de Staphylococcus en las muestras de queso doble crema elaborado en Pamplona, reflejando inadecuadas practicas de higiene y desinfección empleadas a lo largo de toda la cadena de procesamiento del mismo, de tal manera que se debe capacitar a los manipuladores en Buenas Prácticas de Manufactura. Además, se deben controlar la temperatura de almacenamiento de la leche y del producto terminado para minimizar la multiplicación de la bacteria.

El hecho de encontrar en el $24.6 \%$ de las cepas analizadas, genes enterotoxigénicos correspondientes a las toxinas más frecuentemente implicadas en brotes de ETAs, indica que el queso doble crema elaborado en Pamplona puede representar un peligro para la salud pública. 


\section{Acknowledgements}

Universidad de Pamplona. Faculty of Basic Sciences, Department of Microbiology, students of the Semillero of the Investigation Group in Microbiology and Biotechnology, Paola Andrea Naranjo, Yelitza Lizcano and Vanessa Ortega.

\section{Agradecimientos}

A la Universidad de Pamplona. Facultad de Ciencias Básicas, Departamento de Microbiología, estudiantes del Semillero del Grupo de Investigación en Microbiología y Biotecnología, Paola Andrea Naranjo, Yelitza Lizcano y Vanessa Ortega.

\section{REFERENCES}

1. Haagsma J, Polinder S, Stein C, Havelaar A. Systematic review of foodborne burden of disease studies: Quality assessment of data and methodology. Int J Food Microbiol 2013; 166(1):34-47.

2. Yakoubou S, Xu D, Côté JC. Phylogeny of the Order Bacillales inferred from 3' 16S rDNA and 5 '16S-23S ITS nucleotide sequences. Nat Sci 2010; 2(9):990-997

3. Jay J, Loessner M, Golden D. Modern Food Microbiology. Seventh Edition. New York: Springer; 2005.

4. Pinchuk I, Beswick E, Reyes V. Review Staphylococcal Enterotoxins. Toxins 2010; 2(8):2177-2197.

5. Doyle M, Buchanan R. Food Microbiology: Fundamentals and Frontiers. 4 th edition. Washington: ASM Press; 2013.

6. Cretenet M, Even S, Le Loir Y. Unveiling Staphylococcus aureus enterotoxin production in dairy products: a review of recent advances to face new challenges. Dairy Sci Technol 2011; 91(2):127-150.

7. Scallan E, Hoekstra R, Angulo F, Tauxe R, Widdowson M, Roy S, Lones J, Griffin M. Foodborne illness acquired in the United States-Major pathogens. Emerg Infect Dis 2011; 17(1):7-15.

8. López D, Rivero E, Martínez A, Alegret M. Enfermedades transmitidas por alimentos en Villa Clara. Rev Cubana Hig Epidemiol 2013;51(2):203-213.

9. Di Pietro S, Haritchabalet K, Cantoni G, Iglesias $L$, Mancini $S$, Temperoni A, Labanchi J, Barbarossa N, Garcia M, Cofre M, Rosales S, Herrero E, Bigatti R, Orellana O, Larrieu E. Vigilancia epidemiológica de enfermedades transmitidas por alimentos en la Provincia de Río Negro, Argentina, 1993-2001. Medicina 2004; 64(2):120-124.
10. Vanegas M, González L, Martínez A, Buitrago F. Aislamiento y caracterización de cepas de Staphylococcus enterotoxigénicos aislados de quesos en Bogotá. Rev MVZ Córdoba 2008; 13(2):1288-1293.

11. Guerra-Sarmiento M, Palacios-González D, Maestre-Serrano R, Baena-Del Valle J, Gómez-Camargo D. Identificación de Agentes Etiológicos Aislados de Muestras Biológicas en Brote por Intoxicación Alimentaria en el Departamento de Atlántico, Colombia 2008. Rev Cienc Biomed 2013; 4(2):233-241.

12. Santos M, Santos C, González J, López $M$. Brote de intoxicación alimentaría en el municipio de Honda, Tolima, Colombia, Junio de 2009. Inf Quinc Epidemiol Nac 2009; 14(21):321-327.

13. NTC 4779. Norma Técnica Colombiana. Microbiología de alimentos y alimentos para animales. Método horizontal para el recuento de Estafilococos coagulasa positiva (Staphylococcus aureus y otras especies). Bogotá, D.C.: Instituto Colombiano de Normas Técnicas y Certificación (ICONTEC); 2007. URL Disponible en: http://tienda.icontec.org/ brief/NTC4779.pdf

14. Linage B, Rodríguez-Calleja J, Otero A, García-López M, Santos J. Characterization of coagulase-positive staphylococci isolated from tank and silo ewe milk. J Dairy Sci 2012; 95(4):1639-1644.

15. NTC 750. Norma Técnica Colombiana. Productos Lácteos. Queso. Bogotá, D.C.: Instituto Colombiano de Normas Técnicas y Certificación (ICONTEC); 2000. URL Disponible en: http://tienda.icontec.org/brief/ NTC750.pdf

16. Mendonça $\mathrm{M}$, Nogueira $\mathrm{V}$, Keizo $\mathrm{Y}$, Tassinari $O$, Nero L. Foodborne pathogens and microbiological characteristics of raw milk soft cheese produced and on retail sale in Brazil. Foodborne Pathog Dis 2009; 6(2):245-249. 
17. Maldonado R, Llanca L. Estudio de la calidad del queso de mano comercializado en el municipio Girardot, estado Aragua, Venezuela. Rev Cientif FCV-LUZ 2008; 18(4):431-436.

18. Rodríguez C, Caldas L, Ogeerally P. Calidad sanitaria en queso artesanal tipo "telita". Upata, estado Bolívar, Venezuela. Rev Soc Venezolana Microb 2009; 29(2):98-102.

19. Can H, Çelik T. Detection of enterotoxigenic and antimicrobial resistant $S$. aureus in Turkish cheeses. Food Cont 2012; 24(1-2): 100-103.

20. Jakobsen R, Heggebø R, Sunde E, Skjervheim M. Staphylococcus aureus and Listeria monocytogenes in Norwegian raw milk cheese production. Food Microbiol 2011; 28(3):492-6.

21. Giammanco G, Pepe A, Aleo A, D'Agostino V, Milone S, Mammina C. Microbiological quality of Pecorino Siciliano "primosale" cheese on retail sale in the street markets of Palermo, Italy. New Microbiol 2011; 34(2):179-185.

22. Luján D, Valentín M, Molina M. Evaluación de la presencia de Staphylococcus aureus en quesos frescos artesanales en tres distritos de Lima - Perú. Respyn (en línea) 2006. (Fecha de acceso 3 de Abril de 2014); 7(2). URL disponible en: http://www.respyn.uanl.mx/ vii/2/articulos/quesos_frescos-1.htm

23. Komatsu R, Rodrigues M, Loreno W, Santos K. Ocorrência de Staphylococcus coagulase positiva em queijo minas frescal produzido em Uberlândia-MG / Occurrence of Staphylococcus coagulase positiva in fresh minas cheese produced in Uberlândia-MG. Biosci J 2010; 26(2):316-321.
24. Gücükoğlu A, Çadirci Ö, Terzi G, Kevenk TO, Alişarli M. Determination of enterotoxigenic and methicillin resistant Staphylococcus aureus in ice cream. J Food Sci 2013; 78(5):738-741.

25. Valero-Leal K, Rivera-Salazar J, Valbuena, E, Boscán L, Valeris R, Castro G, Briñez W. Caracterización bioquímica y producción de enterotoxinas de cepas de Staphylococcus aureus aisladas de leche cruda y queso fresco artesanal en fincas del estado Zulia. Rev Cientif FCV-LUZ 2012; 22(4):303-314.

26. Ahanotu E, Alvelo-Ceron D, Ravita T, Gaunt E. Staphylococcal Enterotoxin B as a Biological Weapon: Recognition, Management, and Surveillance of Staphylococcal Enterotoxin. Appl Biosaf 2006; 11(3):120-126.

27. Kérouanton A, Hennekinne J, Letertre C, Petit L, Chesneau O, Brisabois A, De Buyser ML. Characterization of Staphylococcus aureus strains associated with food poisoning outbreaks in France. Int J Food Microbiol 2007; 115(3):369-375.

28. Le Marc, Valík I, Medvedová A. Modelling the effect of the starter culture on the growth of Staphylococcus aureus in milk. Int J Food Microbiol 2009; 129(3):306-311.

29. Daza A, Herrera F, Naranjo A. Condiciones higiénico-sanitarias aplicadas en la elaboración de queso doble crema manufacturado en tres empresas de la provincia de PamplonaColombia. Bistua 2013; 11(2):61-73

30. Cabrera C, Gómez R, Zúñiga A. La resistencia de bacterias a antibióticos, antisépticos y desinfectantes; una manifestación de los mecanismos de supervivencia y adaptación. Colomb Med 2007;38(2):149-158. 